Accepted for publication is Service Business in 2007

Partnerships in the provision of services by multi-agencies: Four dimensions of service leadership and service quality

Colin Armistead, Director, Centre for Organisational Effectiveness, Business School, Bournemouth University.

Paul Pettigrew, Visiting Fellow, Centre for Organisational Effectiveness,

Business School, Bournemouth University.

Contact details

(*) Professor Colin Armistead

Director of the Centre for Organisational Effectiveness

The Institute of Business and Law

Bournemouth University

Bournemouth House

Christchurch Road

Bournemouth

Dorset BH1 3LG

UK

Telephone: +44 (0) 1202967321

Fax: +44 (0) 1202298321

email: carmiste@bournemouth.ac.uk 
Partnerships in the provision of services by multi-agencies: Four dimensions of service leadership and service quality

\begin{abstract}
This paper explores the relationship between four key dimensions of service provision through adopting different partnership approaches. These dimensions are identified to describe partnerships as mandatory or voluntary and service provision based on contract or trust. Propositions about the nature and interaction of these variables are presented and combined as a heuristic suggesting complying, constraining and creating modes of partnership-working and service delivery. Examples are provided of these modes in practice. The paper concludes that this heuristic is a useful tool for practitioners to locate their form of partnership-based service delivery within the spectrum identified.
\end{abstract}

Keywords; Partnerships; public services; trust; contract 
The UK government has engaged since 1997 on a programme of 'modernising' the provision of public services, predominately in areas of health and social care, education, local government and regeneration. The policy has aimed at bringing about a step-change in the quality of public services (Economist, 2005, Jas \& Skelcher, 2005). Such transformation has increasingly depended on organisations working together from across the public, private and voluntary sectors in partnerships. The aim has been to increase service levels, including offering more choice in the nature of provision to citizens and to providers in the way they organise and manage resources. The programme of changes has seen an increase in the level of government funding, structural changes and a greater involvement from the private and voluntary sectors in the provision of the services. There has been much debate about the need to 'join-up' provision where a number of agencies are involved in one programme. For instance, child protection services involve agencies providing social care, education, health, housing and specific children's charities. The complexity of these types of services to serve individuals and communities means that one monolithic organisation is unable to deliver everything. Hence a number of organisations need to be involved in some form of relationship through which required services are identified, designed and delivered, i.e. partnership-working.

'Partnership' is prominent in central and local government rhetoric in the UK (e.g. HM Treasury, 2000; Office of the Deputy Prime Minister, 2001) and has been viewed as the route to joining-up and improving service provision. A 
consequence has been that many multi-agency partnerships are imposed on those organisations where they are under government control. In this they differ from many business alliances where organisations have a choice of with whom to partner. Nevertheless the potential of partnerships has been promoted within and between the private, public and voluntary sectors with authors often being willing to give prescriptions for success (e.g. Child \& Mariotti, 1996; Clarke \& Stewart, 1997; Wilson \& Charlton, 1997; Faulkner, 1998; Hutchinson \& Campbell 1998; Dent, 1999; Smith, 1999). But the practical challenges of effective partnership working have been well investigated and articulated by Huxham and co-workers in the context of collaborative working (Huxham, 1996; Huxham \& Vangen, 2001, 2005). They consider the potential difficulties of collaborative working such that other alternatives should be chosen in preference. However once a decision has been made to collaborate there are suggestions to ensure success. We consider that their studies demonstrate clearly that whilst the recent literature is rich in insight drawn from practical experience and contribute to a complex, paradoxical theoretical language of partnership theory there has been little progress towards a general theory of collaboration (by which we mean partnership working) since the work of Gray and Wood over a decade ago (Gray \& Wood, 1991; Wood \& Gray, 1991).

The purpose of this paper is to explore approaches to partnership working from the literature and from the experience of a group of managers engaged in partnerships. We investigate how partnership working practices might affect the way services are delivered. We examine the influence of service 
provision and how a balance between contract and trust affects the quality of services provided, mainly using the services literature and the reported performance of public services. We draw primarily on the UK experience because of the high aspirations of the government to transform the quality of public services. We also use our work over a four year period with managers, predominantly from the public sector in the UK, who are engaged in multisector partnerships (Pettigrew 2003; Armistead, C. \& Pettigrew, P. 2004: Pettigrew, 2006). We attempt to draw out implications for public service leadership in partnerships intent on transforming the quality of services they provide to citizens.

\section{The Quality of Public Services}

Public services in areas like health, education, social care and local government are complex. In a democratic society citizens expect that the state will be involved in the provision of services through government policy, direct funding from taxes and control over the specification of service provision. A government has a duty to respond and care for its citizens (Stewart \& Walsh, 1989). The extent to which the state is directly involved is influenced by beliefs in the use of public or private organisations as the main providers. Citizens in the UK often have a low expectation of the quality of public services, sometimes based on direct or close experience or sometimes forensic media coverage of service failure. For those responsible for the delivery of services there is the challenge of balancing the needs of the 
individual and the collective needs of society. It is more difficult in public than private services to make an assessment of needs and performance because of the greater number of interested parties i.e. stakeholders, including funders, politicians and service-users. It is also more difficult because of the often complex overlapping if not conflicting policy objectives expected to be met from partnership-working.

Just how these needs are determined has changed in the recent past, with moves to include citizens and service-users in the process to a greater extent, as seen for example in early initiatives under the banners of Citizen's Charters in the UK (Morris \& Haigh, 1996) and more recently public service guarantees in Sweden (Madell, 2005). At the same time the recipients of public services have been viewed more as consumers and customers rather than patients, students and citizens. Charters or 'entitlements' offer statements of what they can expect in terms of choice, accessibility, information and responsibility, often expressed as forms of minimum standards and service agreements. These obligations have consequences for the extent to which failures result in the payment of compensation and legal redress.

Government policy has been to set the targets for services including the quality of those services though public service agreements (PSA). The judgement of the quality of provision relies heavily on a regime of regulation, audit and inspection (Boyne, Day \& Walker, 2002) under schemes including Best Value Reviews, Public Service Benchmarking, Comprehensive Performance Assessment and the use of inspection agencies for local 
government, education and health. In the UK there are 13 inspectorates across education, health and social care, local government and criminal justice, with the National Audit Office having a remit across all areas of government expenditure. The public sector has also sometimes borrowed from the private sector the use of business excellence models such as that developed by the European Foundation of Quality Management (EFQM), so that assessment is on the capability to deliver as much as on the results. However despite the use of all these tools the level of customer satisfaction with key public services has been at best been steady if not in decline (Cabinet Office, 2004).

Defining factors of service quality in public services requires close attention to the specific nature of the service. However, the determinants of public service quality fall within the sets of descriptors which have been identified by a range of authors in the services literature (e.g. Gremler, Bitner \& Evans, 1994; Gronroos, 1984; Johnson, 1995; Parasuraman, 1985). For the most part, these capture fairly generic factors such as availability, communication, reliability and responsiveness, which need to be defined more closely within the context of particular services. Trying to identify the relative importance of one factor over another can be complex, not least because of the range of stakeholders who might make judgments on quality of service, but also reconciling the individual and collective needs.

There has been wide debate about the extent to which target setting and an audit and inspection approach actually leads to improvement in service quality 
in public services (Bouckaert \& Peters 2002; Boyne, Day \& Walker, 2002; van Thiel \& Leeuw, 2002). When resources are constrained, a concentration on particular targets can lead to poor performance in others. Typically this occurs when a focus on increasing throughput and reducing costs lead to rushed, fragmented or incomplete service provision. In a complex policy environment it can also lead to unintended consequences which then require to be addressed as a result of the initial and successive interventions (Jessop, 2000). This phenomenon can then lead to a blurring of the initial focus for the service and inexorably to inefficient, ineffective delivery.

\section{Approaches to Partnership}

Partnership working is hard. There are potential pitfalls in setting up, running and dissolving a multi-organisational partnership (Genefke \& McDonald, 2001; Hall et al., 2002; Stuart, 2002; Sullivan \& Skelcher 2002). However, despite a raft of studies over the past 15 years, there is little effective guidance for emergent practice, taking account of the issues confronting partnership practitioners. Only rarely can a template be invoked that will help resolve uncertainty, ambiguity and paradox, which can be considered the hallmark of this quintessential form of post-modern human institution.

There have been many articles, books and training packages developed to assist organisations working in partnership. Increasingly, government agencies have produced guidance, but they tend to be based on their own requirements rather than those of the partnership (Stewart et al., 2002). 
Hutchinson \& Campbell (1998) reviewed the literature for prescriptions on partnership-working and suggested that there is no easily transferable model of partnerships. Nevertheless, the impression given is that there are plenty of prescribed recipes for effective partnership-working. These refer to choosing the 'right' partners, agreeing strategy and objectives for the partnership, having the 'right' people involved with enabling resources, and finally to developing the 'right' processes for service provision and for monitoring performance.

In the UK, many public sector service delivery partnerships result from government policy. They are seen at all levels, for example between central government departments at the highest level to the local provision of services at the other end of the spectrum. Frequently, the membership of partnerships is prescribed by government so that the major public sector agencies are required or clearly expected to participate. When the intention is to bring about transformation through partnerships there are potential problems as Hastings (1996) has identified. If one partner, perhaps under government policy pressure, tries to bring about change, this is often resisted by others. This unidirectional form of transformation is in sharp contrast to a sense of mutuality between organisations which consciously seek not only to influence others but are open to be influenced in transforming services for the ultimate benefit of users.

There is undoubtedly some confusion about terms relating to partnership both within the literature and also among practitioners. Terms such as networking, 
partnerships, alliances, co-operation, collaboration and collaborative advantage are often used interchangeably and without clear distinction. While some authors such as Himmelman (1996) attempt a detailed taxonomy indicating successively more sophisticated degrees of engagement and commitment between organisations, others are happy to regard terms such as partnership and collaboration as being synonymous (Nissan and Burlingame, 2003). These terms can also be used ambiguously to describe a partnership either as an entity or a method of working (Hutchinson and Campbell, 1998). This is a very important issue for the kinds of 'partnerships' with which we are concerned. We suggest it is important to distinguish between partnerships as entities with recognised structures of governance and inter-organisational working practices between agencies which may be collaborative in nature without necessarily constituting a partnership as such. Nevertheless, many collaborations in British public life are labelled 'partnerships' even with no governance infrastructure in place and only a limited degree of genuine interaction involving joint planning and resourcing and service processes. This, in our view, diminishes the term 'partnership' as if it only has to be declaimed in order to exist, when in reality real partnerships may take some time, shared experience and no little pain before becoming effective (Pettigrew, 2006).

Senior managers in public sector agencies are often required or are expected to be members of a large number of partnerships. We have found from the experience of managers who are involved in a wide range of partnerships a variety of reasons for failure, including: 
- Gaps in the organisational membership required for the purpose of the partnership (often private businesses in public sector-led partnerships)

- Unwilling participant organisations and senior managers 'just turning up' through a sense of duty rather than being actively involved

- Conflicting and sometimes hidden agendas, goals and targets between participant organisations and the partnership

- Conflicting allocation of resources/funding between partnerships where one organisation or agency is a member of each (or several) partnerships competing for resources/funding

- Hostility or suspicion about knowledge sharing between agencies

- Conflicting professional cultures and practices in the participating agencies (e.g. between health and social care)

- Inadequate resources available to support and sustain the work of the partnership

- Power struggles between member organisations within the partnership

- A history of previous difficult relationships between partners (Author, 2003)

When partnerships are imposed on managers, for instance by government mandate, there may be a tendency to try to make the partnership work by following a set of prescriptions or check lists which might satisfy government, but which fail to address the dynamics of partnership performance and the causes of partnership failure. Mandated partnerships can address issues of governance in an ambiguous way which may do little to promote collaboration 
between partners. Public sector managers with considerable experience in partnership working view good partnership as involving a process which seeks to draw the best from each organisation in the partnership through gaining the active involvement of senior managers, i.e. a more empowered approach to partnerships (Armistead \& Pettigrew, 2004). These usually have a strong integrated governance structure alongside an approach to partnership-working that engenders active collaboration through identification with the partnership's objectives and ethos and an alignment between the organisation and the partnership through a process of mutual adjustment. This process is referred to in the collaboration literature as institutional isomorphism' (DiMaggio \& Powell, 1983).

In Table 1 we have attempted to identify some of the characteristic of a mandated as distinct from a voluntary approach to partnership.

Insert Table 1 here

Clearly we are emphasising here the contrast between mandatory and voluntary constructs while recognising that many partnerships will display aspects of each at different times. However, our experience is that a particular partnership can be characterised as being related more to one of these dimensions than the other at any given point in time.

\section{Delivery of Services: Contract v Trust}


Many public services are complex in their delivery and increasingly involve a number of organisations across sectors in order to meet quality standards and targets. We have already seen that partnerships are a common framework for bringing organisations together to develop strategies and/or for deploy services. More often than not one or more of the partners are 'bankers' who will allocate funding for service delivery. A variety of mechanisms are employed to allocate funding which include payment based on formal contracts or against annual approved plans. These are formal arrangements including agreed service level agreements. On their own these arrangements rely on working to the detail of the agreement for their success. They are not good, however, for capitalising on informal arrangements which can generate value through goodwill, good working relations, and allowing creative avenues to be explored. Here success is likely to depend as much on the degree to which there is trust between individuals and hence their organisations.

As a working definition of trust we use: 'Trust is one party's willingness to be vulnerable to another party based on a belief that the other party is, competent, open, concerned and reliable' (Mishra, 1996). We recognise that the level of trust is influenced by prior experience, a calculated assessment of the other party or intuition (Coulson, 1998). The way individuals behave in situations where they might choose to collaborate or not for their own advantage when there is no contractual relationship has been explored in the context of the prisoner's dilemma by Axelrod (1984). He demonstrated that in the short term the tendency is for people not to behave collaboratively. 
However, when a relationship extends over time there is greater potential for mutual gains from collaboration. We can see this effect being influenced by the 'shadow of the future' where each party assesses the risk of defecting from a relationship. Breaking trust will probably bring retaliation from the other party leaving both parties worse off than if they continued collaborating. However, we need to recognise that moving towards collaboration can also be influenced by previous contact between the two parties, i.e. the shadow of the past (Pettigrew, 2003, 2006). In some cases this prior experience can make a trusting collaborative relationship very difficult to achieve in the short term.

In the services literature there is evidence that the level of service performance is influenced by the extent to which relationships between parties involved in service provision are based predominately on contract or trust (Coulson, 1998). Relying on contract accepts the requirement to specify precisely the nature of service provision and the levels of service required by way of service level agreements and to devise effective monitoring systems. Trust relies on service professionals using their knowledge to work collaboratively to develop processes and systems and appropriate process measures to deliver agreed levels of service. Distinctions between these different forms of relationship are shown in Table 2.

Insert Table 2 about here

Again we are here emphasising the contrast between the constructs while recognising that many partnerships will display aspects of each in terms of the 
nature of the service, culture and precedent, and the way in which individuals and organisations relate. However, our experience is that service provision in partnerships can typically be characterised as being reliant more on contract than trust. This is especially true where partnerships are mandated rather than voluntary and where large sums of (possibly) pooled budgets are being dispersed or expended.

\section{Combining Approaches to Partnership and Service Provision}

Our exploration of approaches to partnership-working and how service provision might be influenced by aspects of contract and trust lead us to consider how the two constructs might be related.

Our starting point was four propositions developed from the preceding sections, namely:

Proposition 1 - Service provision based on mandatory partnerships is less likely to deliver service quality to satisfy end users

Proposition 2 - Service provision based on voluntary partnerships is more likely to deliver service quality to satisfy end users

Proposition 3 - Service provision based on contract is less likely to deliver service quality to satisfy end users 
Proposition 4 - Service provision based on trust is more likely to deliver service quality to satisfy end users

We have combined these propositions into a heuristic for service provision by partnerships shown in Figure 1 which relate approaches to partnershipworking and the basis for service provision.

Insert Figure 1 about here

It seems to us that the three areas in the diagram express the characteristics of the environment of service provision which we have seen in multi-sector partnerships. Our assigned descriptions of each area attempt to capture the environment in which decisions and actions take place. More detailed characterisation of each is contained in Tables 1 and 2.

Our proposition is that the three positions have strengths and weaknesses:

(a) Complying, where contract takes precedence over trust and is more mandatory than voluntary

This may be acceptable at one end of the scale, for simple commissioned services which require little direct contact between commissioner and commissioned. However, it may also apply in highly complex, financially or politically risk-laden situations where reliance on trust is deemed insufficient to protect the partners. There may be risks of service failure deriving from the lack of trust between senior managers and staff in the participating 
organisations, particularly when things go wrong and the parties resort to blaming each another. The end users of the service are often not considered in such situations as the partners' energies are focused on resolving issues between them.

A good example of this kind of arrangement between parties is the Private Finance Initiative (PFI) in the UK, a form of public-private partnership. It is particularly employed for projects that are large, costly and complex, involving significant capital works, on-going maintenance and sometimes facility management (HM Treasury, July 2003). They may not be mandatory as a matter of principle but become so once the partners agree on a PFI solution in the sense of having to conform to the rules for these specific forms of partnership laid down by Government.

The style of partnership in this case is strictly hierarchical and market-driven, with the public sector (usually Central or Local Government or Government agencies) entering into long-term arrangements (typically 20-30 years) with a private sector consortium. The latter may comprise a number of equity investors who raise finance for the project and which then sub-contracts the construction, maintenance and service provision. The public sector then pays annuities to the consortium providing a commercial return on their investment. This form of arrangement has delivered over 600 operational new public facilities in the UK, including hospitals, schools and roads. 
The value to the public sector is that it can take full advantage of the private sector's perceived project management, innovation, design and risk management skills, justifying the extra cost of raising money from private sources as opposed to the cost of Government borrowing. This kind of arrangement involves significant transaction costs owing to the reliance on complex, detailed contracts and sub-contracts in which risk is apportioned. The object is to leave little or nothing to trust as the complexity and risk is considerable. Contracts are as water-tight as possible and disputes are resolved with reference to legal obligations. Thus, this type of public-private partnership is not suitable in cases where the transaction costs are a considerable proportion of the value of the project. Hence, they are most often used for expensive multi-million pound capital projects.

\section{(b) Constraining, where trust and contract are balanced and which could be mandatory or voluntary or both}

Constraining partnerships imply a balance between trust and contract, and those that are voluntary or mandated. There may be creative processes underlain by contractual obligations. These partnerships offer scope for design and development within these broad parameters and may be a staging point in moving towards more compliant or creative forms. They may hold back the development of responsive service quality because the partnership demonstrates only a partial progression from a mandatory approach to one of empowerment. On the other hand they may demonstrate travel in the opposite direction, possibly as a result of a breakdown of trust or service 
failure. Some partners may be more trusting of some than others. Overall service provision may be defined by reliance on contract in at least some areas. Recipients of the service may perceive the service provision as fragmented and not joined-up when several different organisations are involved. On the other hand the partners may enjoy freedom to design services to respond to the specific needs of clients within broadly defined contracted targets.

Good examples of this type of partnership in England are Education Business Link Consortia. There are 47 of these in England and they provide a formal structure for local education business link providers to work together in the planning and delivery of work-related learning in support of the school curriculum. The aim is to give young people practical experience of the world of work and help them to understand how their learning is essential for their entry into the workforce. Consortia provide in addition a single point of contact for local employers who wish to help young people develop their potential through links with business.

Although a voluntary service for many years previously, since September 2004 there has been a statutory requirement that all young people aged 14-16 years should experience work-related learning as part of a broad and balanced curriculum.

Currently consortia are variously constituted, from charitable trusts to private companies, and rely primarily on funding through the Learning and Skills 
Council (LSC), a Government agency responsible for planning and funding post-16 learning in England up to Higher Education level. This funding allows a range of programmes to be undertaken by consortia, including student work experience placements, teacher placements into business and work-related learning opportunities for young people.

Consortia are accountable under contract to the LSC for the activities it funds and related targets, but are generally free to allocate funding within global budget allocations to each consortium member to undertake specific activities. This allows consortia members to be creative and share experience and skills among its members, with the LSC contract only specifying outputs and budgets rather than prescription on methodology. For example, some consortia develop a portfolio of 'products' derived from their members based on the headline requirements of the LSC contract. Schools choose which of these to buy from the consortium and resources are then allocated on a demand-led basis to successful consortium members. Thus consortium members can be both partners and competitors.

This particular example illustrates a form of partnership operating at the creative end of the restraining spectrum, but inevitably the variegated governance structures and processes within consortia may lead to variable performance and there may be pressure from contracting agencies, such as in this case the LSC, to 'standardise' delivery methods and forms of governance. This may improve the consistency of service across the country 
and be easier to manage from the funder's viewpoint, but may in so doing lose the flexibility to respond to needs in a particular area.

\section{(c) Creating, where trust takes precedence over contract}

Creating suggests an active involvement of a range of partners to develop and deliver service provision which is responsive to the needs of beneficiaries. While there may be formal contracts between parties the quality of their working relationship to provide services is based on trust, which allows good collaborative working. Relationships are altogether much more complex and difficult to characterise than in the simple contract situation. There may be close interactions with key individuals working in a network who socially construct meaning from their shared experience as well as in designing and delivering services. Creativity is linked to service provision being highly responsive and sensitive to changing needs and demands. However, there may be a danger of over-optimism especially in terms of constraints on funding, possible breakdown of trust and unforeseen disputes based on service design specification, aspects of delivery, or interprofessional rivalry, misunderstanding, and differing or conflicting forms of response. 
A good example of this genre of partnership are mental health partnerships in the UK, which generally involve some form of collaboration between Social Services Departments in local authorities and NHS Mental Health Trusts. It has become increasingly recognized that for adult mental health services a joint and integrated approach to mental health services can deliver a number of benefits to service users, for example by having one gateway to access services through a single community mental health team. They can often be a stepping stone on the pathway towards specialist expanded Mental Health Trusts but stop short of the formal legal and accountability framework that is required under Section 31 of the Health Act, 1999.

The style of these partnerships tends to be underpinned by an overall commitment from partners to improve services through integrated line management in order to avoid parallel, and possibly, conflicting services to this particularly vulnerable client group. There is no contract and delivery is usually flexible and tailored to their needs of service users so that they are unaware of any professional or organisational differences between the service deliverers. Thus, these partnerships are entirely voluntary, although there are often professional cultural obstacles between health and social services personnel to be overcome in order to make services effective.

There are usually shared but distinct organisational budgets, and the form of collaborative arrangement is often encouraged by shared national and local delivery targets where each organisation's achievements can contribute to the other's. 
Such creative partnerships are generally set within a governance framework that suits local need. This model will typically include:

- A joint Management Board that oversees the operational management of joint health and social care teams

- A joint Strategy and Performance Board with a performance management function

- Integrated locality management arrangements with jointly appointed managers from health and social services.

A benefit of voluntary, creative partnerships of this type is the opportunity for issues to come to the fore and be addressed productively prior to formal legal partnerships. In the case of mental health integrated partnerships the following partnership aspects have emerged as opportunities for learning and reframing prior to entering into formal agreements:

- Leadership

- Human Resources

- Financial Systems

- Information Systems

- Evaluation of efficiency and effectiveness 


\section{Conclusion}

We have attempted in this paper to provide a heuristic to help partnership practitioners and service providers understand where their provision fits along the four dimensions of mandated or voluntary partnerships, and whether through trust or contract. We believe this model, whilst a simplification of reality, allows practitioners to map their own partnerships and services and suggest directions of travel. In the current political climate in Britain, where bureaucracy is widely seen as a curse on efficient and effective service provision, efforts to streamline services based on trust more than contract are seen as desirable and necessary. Severe pressure on public service budgets in health, social care, education and regeneration tend to accelerate this process. Whilst we recognise that particular forms of partnership fall naturally into one or more of our theoretical forms (e.g. PFIs), we believe that generally partnerships based on trust rather than mandate are more likely, given time to mature, to deliver the more effective, joined-up services that citizens demand. 
We would trust that our model assists policy-makers in making judgements against the direction of travel a particular partnership should take to become more effective

Partnerships and the needs of service users are dynamic and so we believe that our model needs to be seen in this way. Sometimes it may be necessary to choose a particular combination within the locus of the four dimensions to suit prevailing circumstances. It may be necessary, therefore, to institute mandated contracted services over voluntary relationships based on trust within service partnerships. This may be necessary, for example, in the case of a collapse in service delivery where authoritarian intervention is required to avoid hardship. However, our general belief is that wherever possible service partnerships should be striving to build voluntary relationships and build trust over time, as this is the most sustainable way for services to be delivered to suit local needs.

To be successful, however, Government of one form or another has to create a trusting environment that eschews a blame culture when things go wrong (as they will at some time) and instead encourages stability and learning. Thus, politicians should not be tempted to punish those that falter or over-rely on inspection and audit processes to protect themselves from political embarrassment, but do little for the prospect of achieving long term improvement in the effectiveness of service delivery. A more mature understanding of the inherently complex and sometimes chaotic nature of public service delivery by partnerships would, in our view, help considerably in 
supporting and sustaining effective delivery. We hope that the ideas presented in this paper will assist in this understanding.

\section{Acknowledgements}

The authors acknowledge the support of all the managers who have participated in the study, the Bournemouth, Dorset and Poole Learning and Skills Council for funding the work and other colleagues in Bournemouth University Business School who have contributed to the programme.

\section{References}

Armistead, C. \& Pettigrew, P. (2004) Effective partnerships: Building a sub-regional network of reflective practitioners. International Journal of Public Sector Management $17,571-585$

Axelrod, R. (1984) The evolution of co-operation, New York: Basic Books.

Bouckaert, G. \& Peters, B. G. (2002), Performance Measurement and Management: The Achilles Heel in Administrative Modernization, Public Performance and Management Review, 25(4), June , 359-362.

Boyne, G., Day, P. \& Walker R. (2002) The evaluation of public sector inspection: a theoretical framework, Urban Studies, 39(7), 1197-1212. 
Cabinet Office (2004) Customer Satisfaction with Key Public Services, Prime Minister's Office of Public Services Reform, www.cabinetoffice.gov.uk/opsr.

Child, J. \& Faulkner, D. (1998) Strategies of cooperation: Managing alliances, networks and joint ventures, Oxford: Oxford University Press.

Clarke, M. \& Stewart, J. (1997) Partnership and the management of cooperation, Birmingham: University of Birmingham.

Coulson, A. (1998) Trust and contract in public sector management, in Coulson, A. (ed) Trust and Contracts, The Policy Press, Bristol, 9-34.

Dent, S. (1999) Partnering intelligence: Creating value for your business by building strong alliances, Davies Black Publishing, Paulo Alto, Ca.

DiMaggio, P. J. \& Powell, W. W. (1983) The iron cage revisited: Institutional isomorphism and collective rationality in organizational fields. American Sociological Review 48, 147-160.

Economist, 2/19/2005, 374( 8414), 15,

Genefke, J. \& MacDonald, F. (Eds.) (2001) Effective collaboration: Managing the obstacles to success, Palgrave, .Basingstoke.

Gray, B. \& Wood, D. J. (1991) Collaborative alliances: Moving from practice to theory. Journal of Applied Behavioral Science 27, 3-22. 
Gremler D., Bitner, M. J. \& Evans, K. R. (1994) The internal service encounter, International Journal of Service Industries Management, 5(2), 3456.

Gronroos, C. (1984) A service quality model and its marketing implications, European Journal of Marketing, 18 (4), 36-44.

Hall, S., Rogers, S., Skelcher, C., Spencer, K., Smith, M. \& Sullivan, H. (Eds.) (2002) We can work it out: In depth research into development and policy issues for Local Strategic Partnerships, LGA Publications, London.

Hastings, A. (1996) Unravelling the process of partnership in urban regeneration policy. Urban Studies 33, 253-268.

Himmelman, A. (1996) On the theory and practice of transformational collaboration: from social service to social justice. In Huxham, C. (Ed.), Creating collaborative advantage, ( pp19-43), London: Sage.

H.M. Treasury (2000) Public private partnerships: The Government's approach, HM Treasury, London.

H.M. Treasury (2003) PFI: Meeting the investment challenge, July.

Hutchinson, J. \& Campbell, M. (1998) Working in partnership: Lessons from the literature. Research Report RR63, Norwich, UK: Department for 
Education and Employment.

Huxham, C. (1996) Collaboration and collaborative advantage. In Huxham, C. (Ed.), Creating collaborative advantage, (pp.1-18), London: Sage.

Huxham, C. \& Vangen, S. (2001) What makes practitioners tick? Understanding collaboration practice and practising collaboration understanding. In Genefke, J. and McDonald, F. (Eds.,) Effective collaboration: Managing obstacles to success, (pp1-16), Basingstoke: Palgrave.

Huxham, C. \& Vangen, S. (2005) Managing to collaborate: The theory and practice of collaborative advantage, Abingdon, Oxon: Routledge.

Jas, P. \& Skelcher, C, 2005, Performance Decline and the Turnabout in Public Organisations; A Theoretical and Empirical Analysis, British Journal of Management, 11, 195-210

Jessop, R. (2000) Governance Failure. In Stoker, G. (Ed.), The new politics of British local governance, Basingstoke: Macmillan.

Johnson, R. (1995) The determinants of service quality: satisfiers and dissatisfiers, International Journal of Service Industries Management, 6(5), 53-71. 
Madell, T. (2005) From the Citizen's Charter to Public Service Guarantees the Swedish Model, European Public Law, 11,( 2), 261-282.

Mariotti, J. L. (1996) The power of partnerships: The next step, Oxford: Basil Blackwell.

Mishra, A. (1996) Organisational responses to crisis: the centrality of trust, in Kramer, R M \& Tyler T R (eds) Trust in Organisations: frontiers of theory and research, (pp 261-87), London, Sage

Morris, D. \& Haigh, B. (1996) The Citizen's Charter and Quality Management: Harmony or Discord, in Chandler, J. (Ed.), The Citizen's Charter, (pp 67-84)

Nissan, L. G. \& Burlingame, D. F. (2003) Collaboration among institutions: Strategies for nonprofit management education programmes. Indianapolis, IN: The Centre on Philanthropy.

Office of the Deputy Prime Minister (2001) Our towns and cities: The future, Department of Transport and the Regions, London, www.regeneration.detr.gov.uk

Parasuraman, A., Ziethmal, V. and Berry, L. L. (1985) A conceptual model of service quality and implications for future research, Journal of Marketing, (49), Fall, 41-50. 
Pettigrew, P. J. (2003) Power, conflicts and resolutions: A change agent's perspective on conducting action research within a multi-organizational partnership. Systemic Practice and Action Research 16, 375-391.

Pettigrew, P. J. (2006) Transformation and power in a multi-organizational partnership: A case study, Doctoral thesis, Bournemouth University.

Smith, M. (1999) Evaluating community involvement: Tools and techniques for multi-sector partnerships, Occasional Paper 24, School of Public Policy, Birmingham University.

Stewart, J. \& Walsh, K. (1989) The search for quality, Luton: Local Government Management Board, cited in Stuart, M. (2002) Collaborating for change? Managing widening participation in Further and Higher Education, Leicester: NIACE.

Stewart, M. (ed) (2002) Collaboration and co-ordination in area-based initiatives. NRU Research Report No. 1, London: Neighbourhood Renewal Unit.

Stuart, M. (2002) Collaborating for change? Managing widening participation in Further and Higher Education, Leicester: NIACE.

Sullivan, H. \& Skelcher, C. (2002) Working across boundaries: Collaboration in public services, London: Sage. 
van Thiel, S., \& Leeuw, F. L. (2002) The Performance Paradox, Public Performance and Management Review, 25(3), 267-281.

Wilson, A. \& Charlton, K. (1997), Making partnerships work: A practical guide for the public, private, voluntary and community sectors, Joseph Rowntree Foundation, York.

Wood, D. J. \& Gray, B. (1991) Toward a comprehensive theory of collaboration. Journal of Applied Behavioral Science 27, 139-162. 
TABLE 1: Mandatory and voluntary approaches to partnership

\begin{tabular}{|c|c|}
\hline Mandatory Partnerships & Voluntary Partnerships \\
\hline $\begin{array}{l}\text { Ambiguous governance and } \\
\text { accountabilities between partnership } \\
\text { and imposer/funder. }\end{array}$ & $\begin{array}{l}\text { Clear local governance and } \\
\text { accountabilities. }\end{array}$ \\
\hline $\begin{array}{l}\text { Ambiguity over central v local } \\
\text { concerns and priorities. }\end{array}$ & Focus on locally agreed priorities. \\
\hline $\begin{array}{l}\text { Compromise the most likely route to } \\
\text { agreement. }\end{array}$ & $\begin{array}{l}\text { Consensus the most likely route to } \\
\text { agreement. }\end{array}$ \\
\hline $\begin{array}{l}\text { Often an extension of state power } \\
\text { and control. }\end{array}$ & $\begin{array}{l}\text { Expression of desire for local power } \\
\text { and control even if in conflict with } \\
\text { the state. }\end{array}$ \\
\hline $\begin{array}{l}\text { 'Tick box' approach to structure and } \\
\text { process. }\end{array}$ & $\begin{array}{l}\text { Creative, extemporised approaches } \\
\text { to structure and process. }\end{array}$ \\
\hline $\begin{array}{l}\text { Partners specified by funder; limited } \\
\text { scope for change. }\end{array}$ & $\begin{array}{l}\text { Partners join voluntarily on basis of } \\
\text { predicted partnership synergy and } \\
\text { organisational benefits with easy } \\
\text { access for those who want to } \\
\text { contribute. }\end{array}$ \\
\hline $\begin{array}{l}\text { 'Partners' have limited identity with } \\
\text { the 'partnership'. }\end{array}$ & $\begin{array}{l}\text { Partners feel sense of ownership of } \\
\text { the partnership. }\end{array}$ \\
\hline $\begin{array}{l}\text { Tend to last only as long as the } \\
\text { funding. }\end{array}$ & $\begin{array}{l}\text { More sustainable, as long as funding } \\
\text { sources derived from partners are }\end{array}$ \\
\hline
\end{tabular}




\begin{tabular}{|c|c|}
\hline & maintained. \\
\hline $\begin{array}{l}\text { Leadership assumed to rest with a } \\
\text { lead partner, often the 'banker' } \\
\text { specified by the funder, particularly if } \\
\text { central government. }\end{array}$ & $\begin{array}{l}\text { Leadership decided by partners. } \\
\text { More diffused and distributed } \\
\text { approaches explored. }\end{array}$ \\
\hline $\begin{array}{l}\text { Tends to be high-level and strictly } \\
\text { tiered. }\end{array}$ & Multi-tiered, but with more flexibility. \\
\hline $\begin{array}{l}\text { Outputs and outcomes strictly defined } \\
\text { and measured. }\end{array}$ & $\begin{array}{l}\text { Less rigour in measuring outputs } \\
\text { and outcomes and less initial target } \\
\text { setting. }\end{array}$ \\
\hline $\begin{array}{l}\text { Goals, strategy, plans, objectives and } \\
\text { targets specified by funder. }\end{array}$ & $\begin{array}{l}\text { Goals, strategy, plans, objectives } \\
\text { and targets less well specified; } \\
\text { conflicts between organisational } \\
\text { goals and cultures explored } \\
\text { multilaterally. }\end{array}$ \\
\hline $\begin{array}{l}\text { Resources specified and subject to } \\
\text { strict financial control. }\end{array}$ & $\begin{array}{l}\text { Creative resourcing is the norm with } \\
\text { more flexible allocation of resources } \\
\text { and more efforts to seek synergy } \\
\text { among the partners. }\end{array}$ \\
\hline $\begin{array}{l}\text { Partnership processes follow the } \\
\text { prescriptions set by the funder. }\end{array}$ & $\begin{array}{l}\text { Processes less well specified and } \\
\text { articulated; more reliance on } \\
\text { informal understandings. }\end{array}$ \\
\hline $\begin{array}{l}\text { Reliant on the traditional skills of } \\
\text { professionals. }\end{array}$ & $\begin{array}{l}\text { Reliant on the skills of 'boundary } \\
\text { spanners', 'political entrepreneurs' }\end{array}$ \\
\hline
\end{tabular}




\begin{tabular}{|c|c|}
\hline & and 'mavericks'. \\
\hline $\begin{array}{l}\text { Hierarchy relatively more important } \\
\text { than network. }\end{array}$ & $\begin{array}{l}\text { Network relatively more important } \\
\text { than hierarchy. }\end{array}$ \\
\hline $\begin{array}{l}\text { Nature of reality is a 'given', } \\
\text { prescribed by authority. }\end{array}$ & $\begin{array}{l}\text { Nature of reality is more socially } \\
\text { constructed. }\end{array}$ \\
\hline $\begin{array}{l}\text { Traditional professional competencies } \\
\text { are maintained with 'partnering skills' } \\
\text { assumed. }\end{array}$ & $\begin{array}{l}\text { New ways of working across } \\
\text { organisations and traditional skill } \\
\text { sets are explored. Practitioners } \\
\text { encouraged to learn about } \\
\text { partnership working. }\end{array}$ \\
\hline Performance is closely monitored. & $\begin{array}{l}\text { Informal assessment and judgement } \\
\text { more important than formal } \\
\text { mechanisms. }\end{array}$ \\
\hline $\begin{array}{l}\text { Transformational possibilities are } \\
\text { largely unidirectional (Hastings, } \\
\text { 1996). }\end{array}$ & $\begin{array}{l}\text { Possibilities may include mutual } \\
\text { transformation. }\end{array}$ \\
\hline $\begin{array}{l}\text { Partnership is overtly political and } \\
\text { public. }\end{array}$ & $\begin{array}{l}\text { Partnership is less political and less } \\
\text { public. }\end{array}$ \\
\hline
\end{tabular}

TABLE 2: Contrast between service provision based on contract or trust

\begin{tabular}{|lll|l}
\hline Service provision relying on & Service provision relying on Trust
\end{tabular} 


\begin{tabular}{|c|c|}
\hline Contract & \\
\hline $\begin{array}{l}\text { Detailed specification of how service } \\
\text { will be delivered. }\end{array}$ & $\begin{array}{l}\text { Emphasis on service outcomes, } \\
\text { leaving delivery to be designed by } \\
\text { contractor. }\end{array}$ \\
\hline $\begin{array}{l}\text { Emphasis on quantified measures of } \\
\text { service outcomes. }\end{array}$ & $\begin{array}{l}\text { Quantitative and qualitative } \\
\text { approaches. }\end{array}$ \\
\hline $\begin{array}{l}\text { Based on 'tried and tested' } \\
\text { experience. }\end{array}$ & $\begin{array}{l}\text { Open to discussion, mutually agreed } \\
\text { from outset. }\end{array}$ \\
\hline $\begin{array}{l}\text { Inflexible even if circumstances } \\
\text { warrant variation in practice. }\end{array}$ & $\begin{array}{l}\text { Flexible, open to variation based on } \\
\text { experience in delivery. }\end{array}$ \\
\hline $\begin{array}{l}\text { Resolution of service failure based on } \\
\text { contract specification underpinned by } \\
\text { contract law. }\end{array}$ & $\begin{array}{l}\text { Service failure seen as opportunity for } \\
\text { both parties to collaborate to solve } \\
\text { issues for the benefit of service users. }\end{array}$ \\
\hline $\begin{array}{l}\text { Needs of service-users seen as less } \\
\text { important than adherence to the } \\
\text { contract. }\end{array}$ & $\begin{array}{l}\text { Needs of service-users have primacy } \\
\text { over contract. }\end{array}$ \\
\hline $\begin{array}{l}\text { Mutual learning limited by reliance on } \\
\text { contract. }\end{array}$ & $\begin{array}{l}\text { Mutual learning enhanced by focus } \\
\text { on developing trusting relationships } \\
\text { between contractor and contractee. }\end{array}$ \\
\hline $\begin{array}{l}\text { Professional judgement limited by } \\
\text { exigencies of the contract. }\end{array}$ & $\begin{array}{l}\text { Professional judgement valued within } \\
\text { relationship between contractor and } \\
\text { contractee. }\end{array}$ \\
\hline Short-term thinking: win or lose. & $\begin{array}{l}\text { Longer-term relationship building } \\
\text { win/win. }\end{array}$ \\
\hline
\end{tabular}




\begin{tabular}{|l|l|}
\hline Subject to expensive legal dispute & Contract seen as 'back stop' with \\
over perceived non-compliance. & conflict resolution negotiated within \\
& on-going relationship. \\
\hline
\end{tabular}

\section{FIGURE 1: Service Provision by Partnerships}

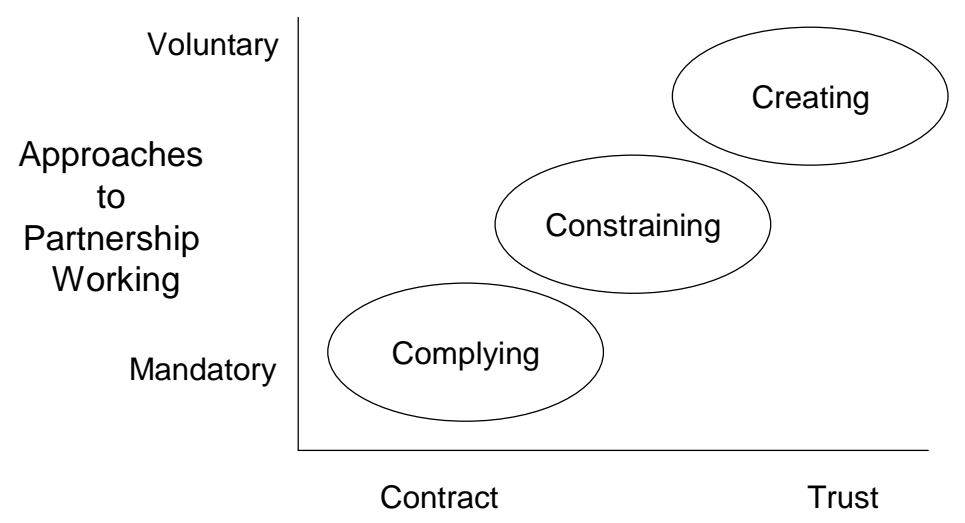

Basis for Service Provision 